\title{
First record of an epibiont protozoan Epistylis sp. (Ciliophora, Peritrichia) attached to Ergasilus chelangulatus (Ergasilidae) in Brazil
}

\author{
Azevedo, RK.*, Brandão, H., Abdallah, VD. and Silva, RJ. \\ Departamento de Parasitologia, Instituto de Biociências, Univ Estadual Paulista - UNESP, Campus de Botucatu, \\ Avenida Prof. Montenegro, s/n, Distrito de Rubião Junior, CEP 18618-970, Botucatu, SP, Brazil \\ *e-mail: azevedork@hotmail.com
}

Received June 13, 2012 - Accepted February 6, 2013 - Distributed May 31, 2014

(With 3 figures)

\begin{abstract}
In the present paper, we described the first record of an epibiont protozoan Epistylis sp. Ehrenberg, 1830 (Ciliophora, Peritrichia) attached to Ergasilus chelangulatus Thatcher and Brasil-Sato, 2008, parasite of Pimelodus maculatus Lacépède, 1803 in Brazil, with electron microscope observations. Fish were collected in Veados River, state of São Paulo and the crustacean Ergasilus chelangulatus being registered for the first time in this river, expanding its geographical distribution in Brazil.
\end{abstract}

Keywords: Epistylis, Ergasilus chelangulatus, Veados River, Brazil, epibiosis.

\section{Primeiro registro do protozoário epibionte Epistylis sp. (Ciliophora, Peritrichia) aderido à Ergasilus chelangulatus (Ergasilidae) no Brasil}

\begin{abstract}
Resumo
No presente trabalho nós descrevemos o primeiro registro de um protozoário epibionte Epistylis sp. Ehrenberg, 1830 (Ciliophora, Peritrichia) aderido à Ergasilus chelangulatus Thatcher e Brasil-Sato, 2008, parasito de Pimelodus maculatus Lacépède, 1803 no Brasil, com observações de microscopia eletrônica. Os peixes foram coletados no Rio dos Veados, estado de São Paulo e o crustáceo Ergasilus chelangulatus está sendo registrado pela primeira vez neste rio, ampliando sua distribuição geográfica no Brasil.
\end{abstract}

Palavras-chave: Epistylis, Ergasilus chelangulatus, Rio dos Veados, Brasil, epibiose.

\section{Introduction}

The genus Epistylis Ehrenberg (1830) includes approximately 100 described species of sessile ciliates, most of which are believed to live as epibionts on crustaceans, insects, rotifers, and aquatic plants in marine and freshwater environments (Utz, 2007). In addition, Epistylis spp. can also be found on the skin and fins of fish and on the carapaces of turtles (Crites, 1977).

Epibiosis is a facultative association of two organisms, the epibiont and the basibiont. The term "epibiont" includes organisms that, during the sessile phase of their life cycle, are attached to the surface of a living substratum, whereas the "basibiont" lodges and constitutes a support for the epibiont (Fernandez-Leborans and Tato-Porto, 2000).

Any host-parasite relationship is dynamic, shifting along a continuum precisely definable only at an instant in time and space. Much as in a waltz, the "partners" are constantly adapting to each other's 'moves' in response to the presence, or potential presence, of one an other (Horwitz and Wilcox, 2005). Epibionts having crustaceans as hosts must be adapted to leave their host and to re-colonise the same or another substrate, after each moult (Utz and Coats,
2005). Some authors have found Epistylis attached only to adult copepods. According to Bozkurt and Genc (2009), Epistylis could be absent from the younger copepodit stages because moulting effectively removes epibionts. In addition, the greater body surface area of adults may make them more attractive to the epibionts.

According to Utz (2007), living hosts often represent a suitable attachment site for peritrichs and other sessile organisms, because the water currents passing by the host can supply the epibionts with food particles and can facilitate the removal of waste material. Mechanisms of recognition of a living substrate or of specific hosts by epibionts are still unknown. However, it is believed that chemical, mechanical, or even electrical cues may be involved in the recognition of the substrate for colonisation, as well as in the process of formation of free-living stages when the host moults or dies (Utz and Coats, 2005).

Crustaceans and molluscs commonly serve as substrata for sessile peritrich ciliates, and several previous studies have focussed on these relationships. Studies of epibiosis between Epistylis spp. and parasitic crustaceans are scarce. 
This topic has, primarily been investigated by Van As and Viljoen (1984), who have described E. branchiophila Perty-Stein, 1859, E. epibirnimiana, and E. cyprinaceae Van As and Viljoen, 1984 on Lernaea cyprinaceae Linnaeus (1758). Shafir and Oldewage (1992) have recorded Epistylis sp. on Argulus americanus Wilson (1902); A mississippiensis Wilson (1916); A. lepidostei Kellicott (1877); and A. flavescens Wilson, 1916 from Illinois, U.S.A. These authors have observed rust-coloured lesions characteristic of crustacean shell disease. Silva-Souza and Rosim (2005) have recorded Epistylis sp. on lernaeid crustaceans from Córrego do Feijão, São Paulo, Brazil. Abdallah et al. (2011) recorded Epistylis sp. on copepoda Amplexibranchius bryconis Thatcher and Paredes (1985) from Peixe's River, the state of São Paulo, Brazil.

\section{Material and Methods}

We examined 10 specimens of the fish Pimelodus maculatus Lacépède (1803) collected from the Veados River (23 15' 20.7'S $48^{\circ} 37^{\prime} 17^{\prime}$ 'W), in the state of São Paulo, Brazil, from 25 to 27 July 2011 (Figure 1). The gills, skin, nostrils, and oral cavity were examined in search of parasitic crustaceans. The crustaceans found were fixed in $70^{\circ} \mathrm{GL}$ alcohol, were subsequently mounted between a slide and a coverslip using Gray \& Wess, and were identified according to Thatcher and Brasil-Sato (2008). The sessile ciliates were mounted in Gray \& Wess between a slide and a coverslip, since this mounting medium was very satisfactory for this group of parasites. Micrographs were taken with a Leica DM5000 microscope equipped with differential interference contrast (DIC) optics. Other specimens were prepared for scanning electron microscopy using standard techniques (Dedavid et al., 2007) and analysed with a FEI Company Quanta 200 scanning electron microscope in the Centre of Electron Microscopy of the Instituto de Biociências do Campus de Botucatu-UNESP. Voucher specimens of the Crustacea were deposited in the Coleção Helmintológica do Instituto de Biociências de Botucatu (CHIBB), in the state of São Paulo, Brazil, with the number CHIBB 7053.

\section{Results and Discussion}

In this study, we found the parasitic copepod, Ergasilus chelangulatus Thatcher and Brasil-Sato, 2008 (Figures 2 and 3) a member of the family Ergasilidae, order Poecilostomatoida parasitising the gills of $P$. maculatus. This species has been described by Thatcher and BrasilSato (2008) parasitising the gills of P. maculatus from the upper São Francisco River. The specimens collected here presented the measurements very similar to those found by Thatcher and Brasil-Sato (2008). Members of this family can produce epithelial hyperplasia, metaplasia, and lamellar fusion in the gill filaments of their hosts. Hence, they may cause the death of the fish by reducing respiratory efficiency and by paving the way for secondary bacterial invaders (Thatcher, 1991).

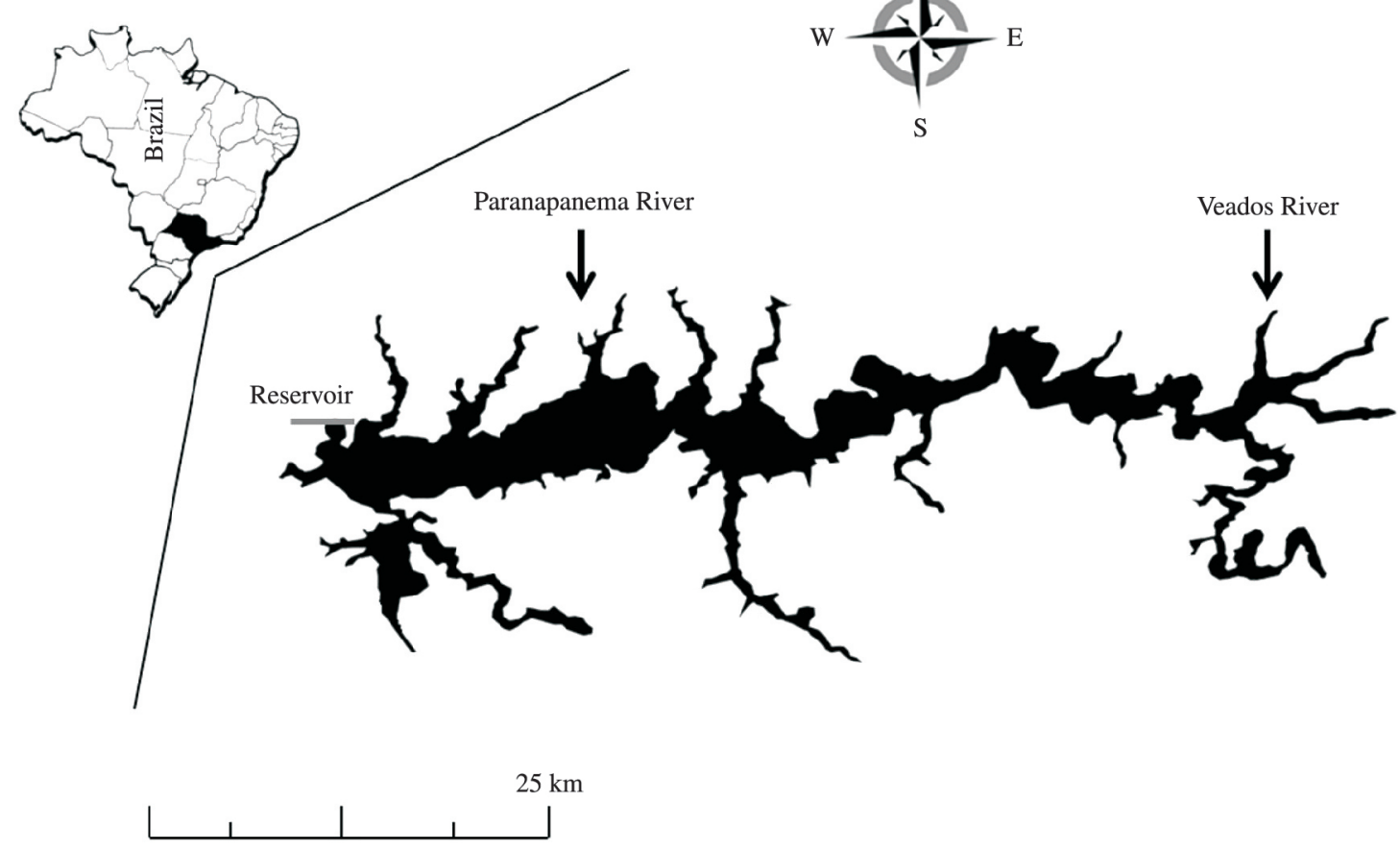

Figure 1. Location of the reservoir Jurumirim no Alto Paranapanema River, SP and sampling area in the Veados River (arrow). (Source: satellite image of GoogleEarth - DigitalGlobe). 


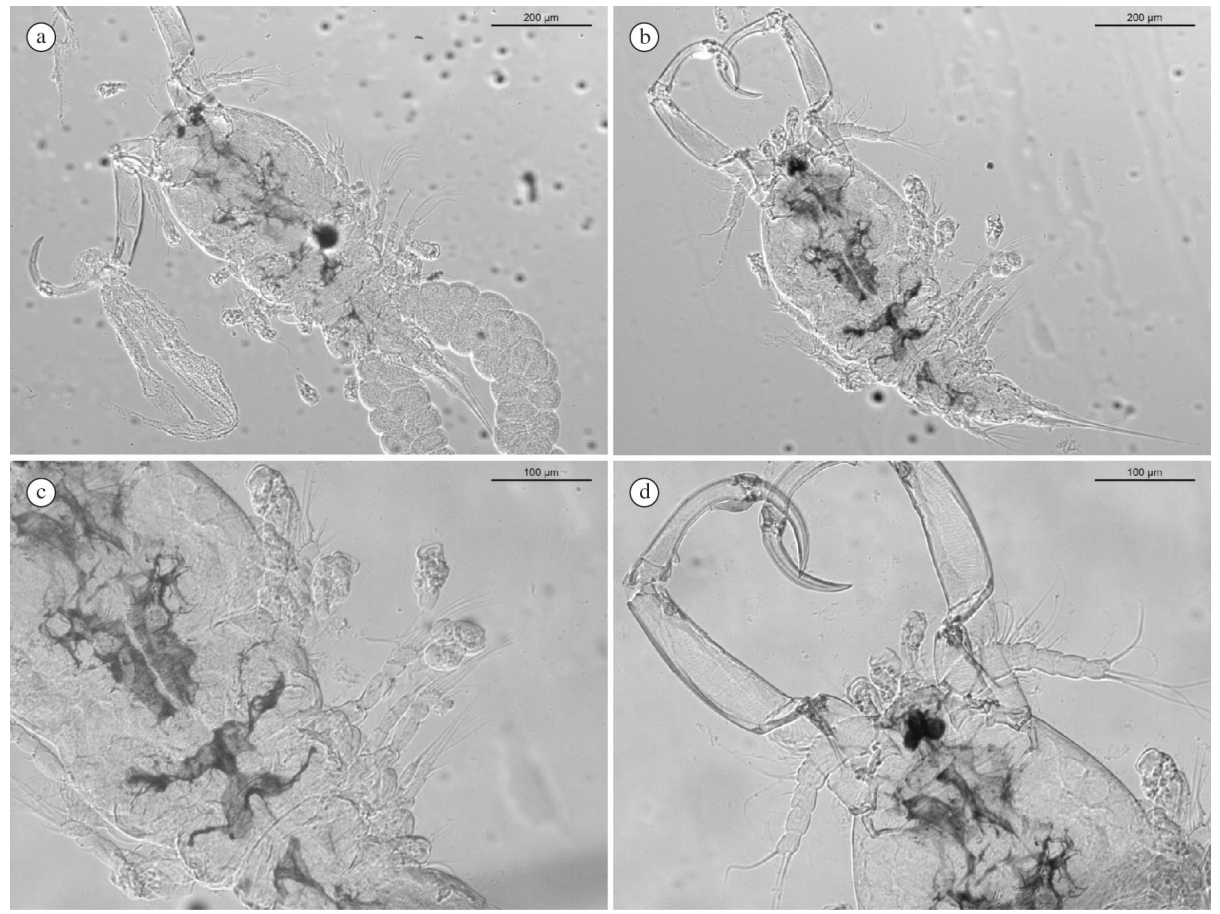

Figure 2. Ergasilus chelangulatus Thatcher \& Brasil-Sato, 2008. a, b. specimens with a large portion of its body covered by Epistylis sp.; c. legs of a specimen of E. chelangulatus covered by Epistylis sp.; d. head of a specimen of E. chelangulatus covered by Epistylis sp.

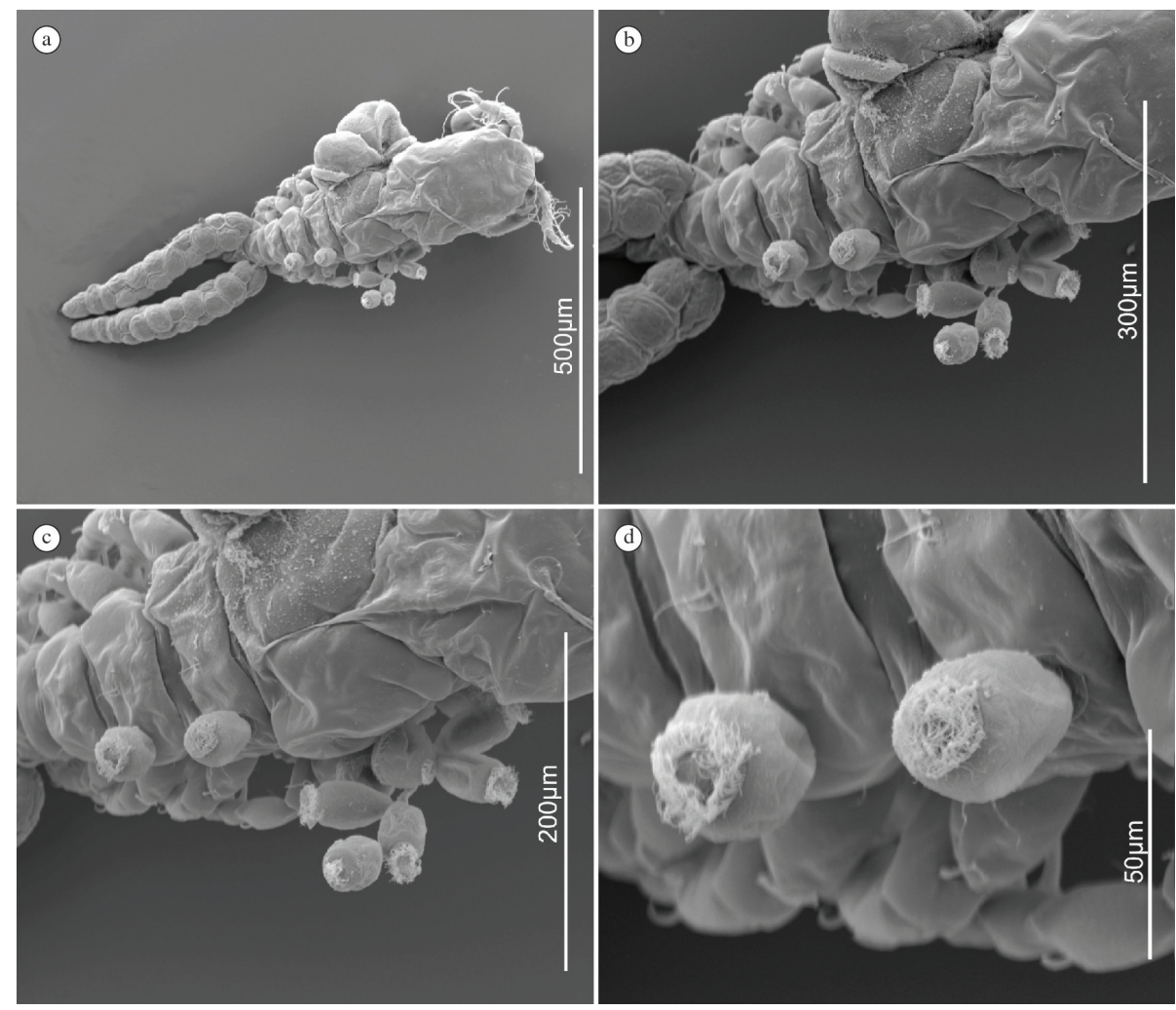

Figure 3. Scanning Electron Microscope (SEM) of Ergasilus chelangulatus Thatcher \& Brasil-Sato, 2008, female. a. Dorsal view of basibiont with Epistylis sp. attached; b, c. Thorax with Epistylis sp. attached; d. Detail of insertion of Epistylis sp. on thorax of basibiont. 
In the present study, all fishes were parasitised by E. chelangulatus (100\%) and $20 \%$ of the copepods collected were in turn parasitised by Epistylis sp. on at least some part of the body. In some cases, this protozoan occurred over a large portion of the copepod's body and on the copepod's legs.

In general, epibiosis has been viewed as a commensal relationship. However, several studies have shown that epibionts affect their hosts in different ways, including decreased survival and fecundity, lesions and diseases, disturbance of locomotion, decreased competitive ability, increased susceptibility to predation, increased energy demands, and faster sinking rates (Bozkurt and Genc, 2009). The last-mentioned observations may thus imply that the presence of the ciliate protozoan could quite possibly have negative effects on the population of the copepod.

It is the first record of the ciliate Epistylis sp. attached to this crustacean in Brazil. After being described by Thatcher and Brazil-Sato (2008), this is the first record of E. chelangulatus parasitizing P. maculatus outside their type locality. This work has expanded the known geographic distribution of these two parasitic species.

Acknowledgements - Authors would like to thank to collaborators from Center of Electron Microscopy of the Instituto de Biociências do Campus de Botucatu-UNESP who assisted with the scanning electron microscopy. Rodney K. de Azevedo was supported by a student fellowship from FAPESP (2010/06564-5), Heleno Brandão was supported by a student fellowship from CAPES (Aux-PEPNPD 3005/2010), Vanessa D. Abdallah was supported by a student fellowship from FAPESP (2009/51726-6) and Reinaldo José da Silva was supported by a Research fellowship from CNPq (312590/2009-1) and FAPESP.

\section{References}

ABDALLAH, VD., AZEVEDO, RK. and SILVA, RJ., 2011. First record of an epibiont protozoan Epistylis sp. (Ciliophora, Peritrichia) attached to Amplexibranchius bryconis Thatcher \& Paredes, 1985 (Copepoda, Ergasilidae) from Peixe's River, state of São Paulo, Brazil. Crustaceana, vol. 84, no. 9, p. 1139-1144. http://dx.doi.org/10.1163/001121611X584352.

BOZKURT, A. and GENC, E., 2009. First record of the epibiont protozoan Epistylis sp. on zooplankton (Copepoda, Cladocera, and Rotifera) from the Asi River, Turkey. Crustaceana, vol. 82, no. 5, p. 515-530. http://dx.doi.org/10.1163/156854009X407687.

CRITES, JL., 1977. The occurrence of Epistylis niagarae (Cliophora: Peritrichida) on fishes from the island region of western Lake Erie. The Ohio Journal of Science, vol. 77, p. 193-194.

DEDAVID, BA., GOMES, CI. and MACHADO, G., 2007. Microscopia eletrônica de varredura: aplicações e preparação de amostras. Porto Alegre: EDIPUCRS. 60 p.

EHRENBERG, CG., 1830. Neue Beobachtungen über blutartige Erscheinungen in Aegypten, Arabien und Sibirien, nebst einer Uebersicht und Kritik der früher bekannten. Annual Review of Physical Chemistry, vol. 94, no. 4, p. 477-514. http://dx.doi. org/10.1002/andp.18300940402.
FERNANDEZ-LEBORANS, G. and TATO-PORTO, ML., 2000. A reviev of the species of protozoan epibionts on crustaceans. II. Suctorian ciliates. Crustaceana, vol. 73, no. 10, p. 1205-1237. http://dx.doi.org/10.1163/156854000505209.

HORWITZ, P. and WILCOX, BA., 2005. Parasites, ecosystems and sustainability: an ecological and complex systems perspective. International Journal for Parasitology, vol. 35, no. 7, p. 725-732. http://dx.doi.org/10.1016/j.ijpara.2005.03.002. PMid:15925596

KELLICOTT, DS., 1877. Description of a new species of Argulus. Bulletin of the Buffalo Society of Natural Sciences, vol. 3, p. 214-216.

LACÉPÈDE, BGE., 1803. Histoire naturelle des poissons. Bulletin of the Bureau of Fisheries, vol. 5, p. 1-803.

LINNAEUS, C., 1758. Tomus I. Systema naturae per regna tria naturae, secundum classes, ordines, genera, species, cum characteribus, differentiis, synonymis, locis. Editio decima, reformata. Holmiae, vol. 1-4, p. 1-824. [Laurentii Salvii]

SHAFIR, A. and OLDEWAGE, WH., 1992. Dynamics of a fish ectoparasite population opportunistic parasitism in Argulus japonicus (Branchiura). Crustaceana, vol. 62, no. 1, p. 50-64. http://dx.doi.org/10.1163/156854092X00046.

SILVA-SOUZA, AT. and ROSIM, DF., 2005. Parasitismo de peixes do córrego do Feijão, São Carlos, São Paulo, Brasil por crustáceo lerneídeo em epibiose com Epistylis sp. (Ciliophora: Peritrichia: Sessilida). Parasitologia Latinoamericana, vol. 60, p. 349.

THATCHER, VE., 1991. Amazon fish parasites. Amazoniana, vol. 11, p. 1-568.

THATCHER, VE. and PAREDES V., 1985. A parasitic copepod, Amplexibranchius bryconis gen. et sp. nov. (Ergasilidae: Acusicolinae) from a Amazonian fish and remarks on the importance of leg morphology in this subfamily. Amazoniana, vol. 9 , p. 205-214.

THATCHER, VE. and BRASIL-SATO, MC., 2008. Ergasilus chelangulatus sp. nov. (Copepoda: Ergasilidae) a branchial parasite of the freshwater catfish, Pimelodus maculatus from the upper São Francisco River, Brazil. Revista Brasileira de Zoologia, vol. 25 , no. 3, p. 512-514.

UTZ, LRP., 2007. First record of Epistylis plicatilis (Ciliophora: Peritrichia) attached to Pomacea canaliculata (Mollusca: Gastropoda) in southern Brazil. Zootaxa, vol. 1454, p. 49-57.

UTZ, LRP. and COATS, D.W., 2005. The role of motion in the formation of free-living stages and attachment of the peritrich epibiont (Ciliophora, Peritrichia). Biociências, vol. 13, no. 1, p. 69-75.

VAN AS, JG. and VILJOEN, S., 1984. A taxonomic study of sessile peritrichs (Ciliophora: Peritricha) associated with crustacean fish ectoparasites in South Africa. South African Journal of Zoology, vol. 19 , no. 4 , p. $275-279$.

WILSON, CB., 1902. North American parasitic copepods of the family Argulidae, with a bibliography of the group and a systematic review of all known species. Proceedings of the United States National Museum, vol. 25, no. 1302, p. 635-742.

-, 1916. Copepod parasites of fresh-water fishes and their economic relations to mussel glochidia. Bulletin of the United States Fish, vol. 34 , p. 333-374. 